\title{
Analysis of Natural Gas Consumption by the Industrial Sector of Bangladesh
}

\author{
Mahbubur Rahman* and Mohammad Tamim \\ PMRE Department, Bangladesh University of Engineering and Technology, Dhaka-1000 \\ Lutfar Rahman \\ Petrobangla, Dhaka
}

\begin{abstract}
The natural gas consuming sectors in Bangladesh are: i) Power, ii) Fertilizer, iii) Industry, iv) Captive power, v) Domestic, vi) Commercial, and vii) Transportation (CNG). Broad sectoral consumptions are reported in various literatures and reports, however, further breakdown of the data are difficult to find, and neither reported. The combined consumption of fertilizer, industry and captive power sectors is a significant portion of national gas consumption. This paper presents for the first time an in-depth analysis of the industrial sector gas consumption. Data were collected for each type of industry, and grouped according to the United Nations Framework Convention for Climate Change (UNFCCC). Captive generation is included in the industrial sector consumption, unlike the usual practice of considering it under the power generation. It is noticed that garments, textile and leather industries together have shown remarkable growth in the last decade. All the industries are more or less related to the national GDP growth. Some are export oriented while others address the internal market. Therefore analysis presented here should be helpful for policy makers to prioritize the sectors in case preferential supply and tariff adjustments become necessary.
\end{abstract}

\section{Introduction}

Natural gas is the most important fuel for Bangladesh both in terms of energy and diversity of use. Bangladesh Oil, Gas and Mineral Resources Corporation (Petrobangla) is entrusted with the responsibilities of the gas and coal sectors of Bangladesh. Subsidiaries under Petrobangla are responsible for exploration, production, transmission, distribution and marketing of natural gas to the end users.

The consumption figures by the broad sectors are easily available because these are regularly reported in various reports and literature. However, further breakdown of the data are hard to find, and are not reported regularly. There is a perception in the society that introduction of $\mathrm{CNG}$ and large amount of wastage in the domestic sector significantly contributed to the gas shortage. In reality, however, the power sector is the largest single consumer of natural gas. It is followed by the fertilizer sector. The combined consumption of fertilizer, industry and captive power sectors is a significant portion of national gas consumption. All other sectors are relatively smaller. Fertilizer sector remained static for a long time, while the rapid industrialization has resulted in remarkable growth in the gas demand of the industrial sector. The increase in demand in the captive generation is almost parallel to that in the industrial sector. Therefore the industrial sector needs more indepth analysis to understand the relative impacts and trends of various industries on the gas consumption and future demands.

\footnotetext{
* Corresponding Author: Mahbubur Rahman

Email: mahbuburrahman@pmre.buet.ac.bd
}

Identifying each industry, grouping them in some consistent manner, and tallying their consumption figures over a period of time is a daunting task, given the state of data management practice by the local oil and gas industry. This paper presents for the first time an in-depth analysis of the industrial sector consumption growth over the period from 2001 to 2005 (Rahman, 2007). In this work the definition of the industrial sector was widened to include fertilizer and captive power sectors.

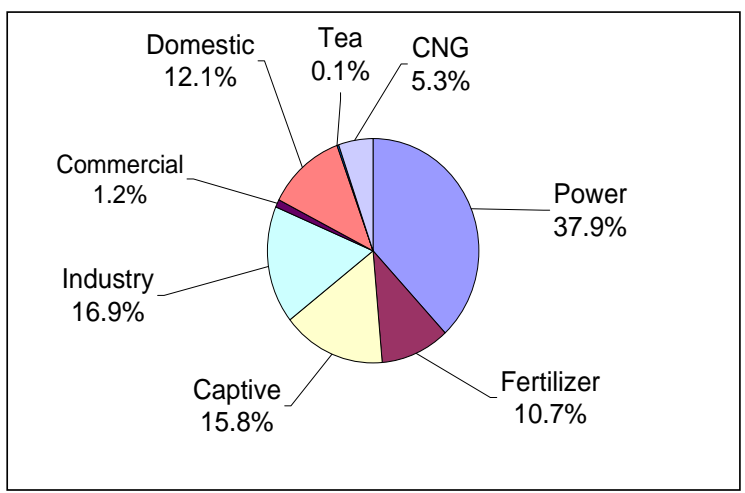

Fig.1. Natural Gas Consumption by Different Sectors (200910)

\section{Natural Gas Consumption}

In Bangladesh, natural gas is used for electricity generation, urea fertilizer production, industrial process heating, captive power generation, and household cooking. It is also being used in the transportation 
sector in the form of CNG since 2005. Fig. 1 shows the natural gas consumption by various sectors during the fiscal year 2009-10. It represents the traditional sectoral split (Petrobangla MIS, 2011).

Fig.1 clearly shows the dominance of the power sector. Fertilizer, traditionally the $2^{\text {nd }}$ largest consumer, is already behind industry, domestic and captive power. Industrial sector, together with fertilizer and captive power, consumed about $43.4 \%$ of the total gas, the largest share of national consumption. Power sector follows closely in the $2^{\text {nd }}$ position. Consumption in the domestic sector, although not small (12.1\%), is incurred by a very large number of customers. CNG sector had a modest beginning with only $1.3 \%$ NG consumption during 2005-06, but rapidly increased to the current level of $5.3 \%$. Table 1 shows the change of gas consumption in the last five years (2004-05 to 2009-10) for different sectors (Petrobangla MIS 2011). It shows that consumption in the fertilizer sector decreased under all three distribution companies, and nationally it decreased by $31 \%$. Power sector consumption decreased by $15 \%$ under BGSL. All other sectors show increasing trend. $\mathrm{CNG}$ and captive power sectors showed astounding rates of increase. One needs to analyze whether these are following normal market mechanism, or being caused by other factors such as Governmental interventions.

It is known that from 2008 onwards the nation faced gas shortage; even though gas production actually increased, it was not sufficient to meet the growing demand. To address the severe power crisis, the authorities temporarily shut down some of the large fertilizer factories and diverted the gas to the power plants. This should explain the negative trend in the fertilizer sector. Some power plants also faced unscheduled shut downs due to technical problems and sometimes due to fuel shortage, which explains the negative trend in the power sector. The captive power sector came about when the utilities were not able to maintain power supply per demand of the industries. The authorities allowed the industrial entities to set up their own power plants and provided extra gas connections. Since then many industries opted for captive generation. Thus the growth in captive generation was quite remarkable, and almost parallel to the industrial growth. This trend will continue if the grid power situation is not improved significantly. $\mathrm{CNG}$ was introduced and promoted by the government in 2005 to address the severe air pollution in Dhaka during the 90's. It had a modest beginning but quickly became popular. In the next 5 years its growth surpassed all predictions. It is however, expected that the $\mathrm{CNG}$ sector despite having dramatic rise will eventually flatten out due to market saturation and interventions like price hike, restriction on dispensing time, etc. The domestic sector should also slow down because the authorities have severely restricted gas connections to the domestic sectors. LPG is being promoted instead for household use. Similar measures are also applied to the industrial sector. These measures will remain in place until gas production and supply are significantly improved. These measures will adversely affect the natural growth trends of the related sectors.

The focus of the paper is the industrial sector, which is analyzed in the next section.

\section{The Industrial Sector}

Analysis presented in this section is based on the data available for the period 2001-2005 (Rahman, 2007). Unfortunately the latest data was not available. Traditional reporting practice in Bangladesh is to aggregate all types of industries except the fertilizer in to a single group called the "Industrial" sector. The Fertilizer manufacturing is usually treated and reported as a separate sector because it had been the single largest consumer of natural gas. Power generation surpassed it in the mid-70's.

Table 1: Increase/Decrease of gas consumption by different sectors (2004-05 to 2009-10), $\Delta$ (change) is in MMCM

\begin{tabular}{|c|c|c|c|c|c|c|}
\hline 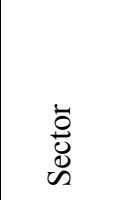 & 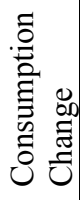 & 己ِ & $\underset{D}{\ddot{D}}$ & 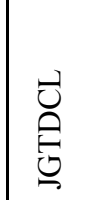 & 己ِ & 胥 \\
\hline \multirow[t]{2}{*}{ Power } & $\Delta$ & 1,723 & -109 & 480 & -55 & 2,039 \\
\hline & $\%$ & 40 & -15 & 146 & -9 & 34 \\
\hline \multirow[t]{2}{*}{ Fertilizer } & $\Delta$ & -437 & -382 & -8 & 0 & -828 \\
\hline & $\%$ & -30 & -37 & -5 & 0 & -31 \\
\hline \multirow[t]{2}{*}{ Captive } & $\Delta$ & 1,797 & 255 & 38 & 27 & 2,117 \\
\hline & $\%$ & 201 & 173 & 122 & 3,352 & 197 \\
\hline \multirow[t]{2}{*}{ Industry } & $\Delta$ & 1,565 & 224 & 99 & 13 & 1,901 \\
\hline & $\%$ & 130 & 106 & 255 & 160 & 130 \\
\hline \multirow[t]{2}{*}{ Comm. } & $\Delta$ & 59 & 25 & 3 & 6 & 92 \\
\hline & $\%$ & 68 & 64 & 28 & 950 & 67 \\
\hline \multirow[t]{2}{*}{ Domestic } & $\Delta$ & 556 & 200 & 46 & 52 & 854 \\
\hline & $\%$ & 53 & 58 & 50 & 762 & 57 \\
\hline \multirow[t]{2}{*}{$\mathrm{CNG}$} & $\Delta$ & 626 & 243 & 74 & 68 & 1,010 \\
\hline & $\%$ & 713 & 1,601 & 13,114 & & 976 \\
\hline
\end{tabular}

The captive power generation is also usually treated and reported as a separate sector. Analysis presented in this paper includes three sectors: i) Fertilizer, ii) Industry, 
and iii) Captive power. Fertilizer, despite its size or role, is just another industry. It is the normal practice all over the world to provide grid power to the industries, which is usually done by the power utilities. In Bangladesh the scenario is quite different. As the utilities were not able to supply grid power as per demand of the industry, the use of captive power came about. It is not to say that every industrial unit has a captive generation unit as well, but it should be emphasized that wherever a captive generation unit exists, it is coupled to one or more industrial units. Therefore captive generation should be added to the industrial sector consumption. Industrial, fertilizer and captive sectors together consumed about $38 \%$ of the total gas during 2005-06, which was quite close to the power generation sector consumption to that time.

Therefore the consumption trends in the industrial sector must be critically analyzed to undertake any conservation, efficiency improvement, or UFG reduction measures to make a meaningful impact. The number and type of industries is quite large, which includes garments and textile, cement, ceramic and glass, metal processing, plastic and rubber, etc. There should be some consistent way to group these industries. The United Nations Framework Convention for Climate Change (UNFCCC) provides guidelines regarding the grouping of industries according to their activities, which was adopted in this paper. Table 2 shows the total natural gas consumption, i.e., including captive generation, by the different types of industries during the period 2000-01 to 2004-05.

Table 2: Yearly Consumption of Natural Gas by Different Industries (MMCM)

\begin{tabular}{|c|c|c|c|c|c|}
\hline \multirow[t]{2}{*}{ Industry Type } & \multicolumn{5}{|c|}{ Year } \\
\hline & $00-01$ & $01-02$ & $02-03$ & 03-04 & $04-05$ \\
\hline Fertilizer & 2,505 & 2,231 & 2,715 & 2,627 & 2,661 \\
\hline $\begin{array}{l}\text { Textile and } \\
\text { Leather }\end{array}$ & 887 & 1,004 & 1,254 & 1,459 & 1,681 \\
\hline Iron \& Steel & 110 & 119 & 144 & 156 & 172 \\
\hline $\begin{array}{l}\text { Non-specified } \\
\text { Industry: }\end{array}$ & 178 & 275 & 274 & 334 & 382 \\
\hline $\begin{array}{l}\text { Food } \\
\text { Processing, } \\
\text { Beverages \& } \\
\text { Tobacco }\end{array}$ & 86 & 91 & 109 & 125 & 148 \\
\hline $\begin{array}{l}\text { Non Metallic } \\
\text { Minerals }\end{array}$ & 117 & 117 & 128 & 143 & 155 \\
\hline Chemicals & 77 & 81 & 92 & 93 & 98 \\
\hline $\begin{array}{l}\text { Pulp, Paper \& } \\
\text { Print }\end{array}$ & 46 & 51 & 58 & 69 & 78 \\
\hline $\begin{array}{l}\text { Non-Ferrous } \\
\text { Metal }\end{array}$ & 3 & 4 & 4 & 3 & 3 \\
\hline Machinery & 5 & 4 & 4 & 4 & 4 \\
\hline Total & 4,013 & 3,977 & 4,781 & 5,014 & 5,382 \\
\hline
\end{tabular}

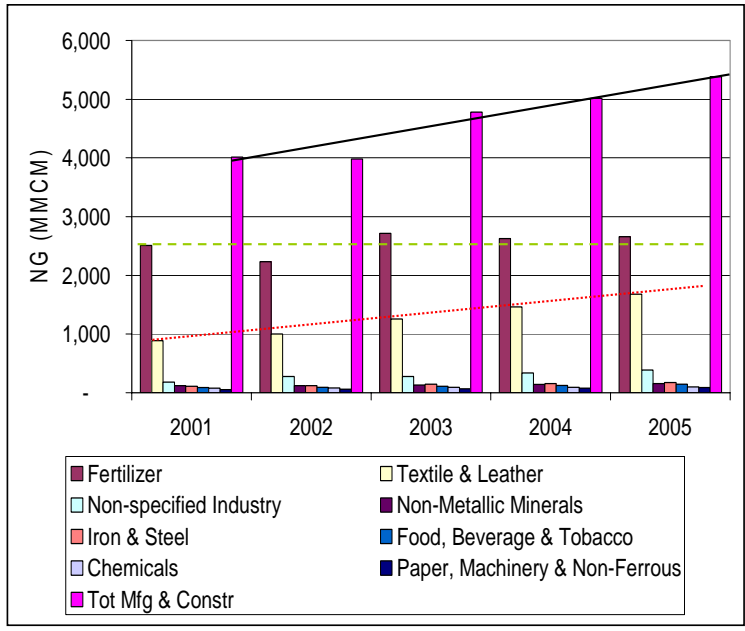

Fig. 2: Yearly Consumption of Natural Gas by Different Industries (2001-05)

Fig. 2 is a graphical rendering of Table 2 (Petrobangla, 2007). It can be seen from Table 2 and Fig. 2 that the total consumption is steadily rising. It is interesting to note that the consumption by the fertilizer industry remained somewhat steady, although as a single industry it is still the largest consumer. It was shown in Table 1 that fertilizer industry has actually gone down since 2005. The textile and leather group is steadily rising, and it is quite possible that it will surpass the fertilizer industry in the future. All other industries also showed moderate increase, while non-ferrous metal and machinery showed slightly decreasing trends.

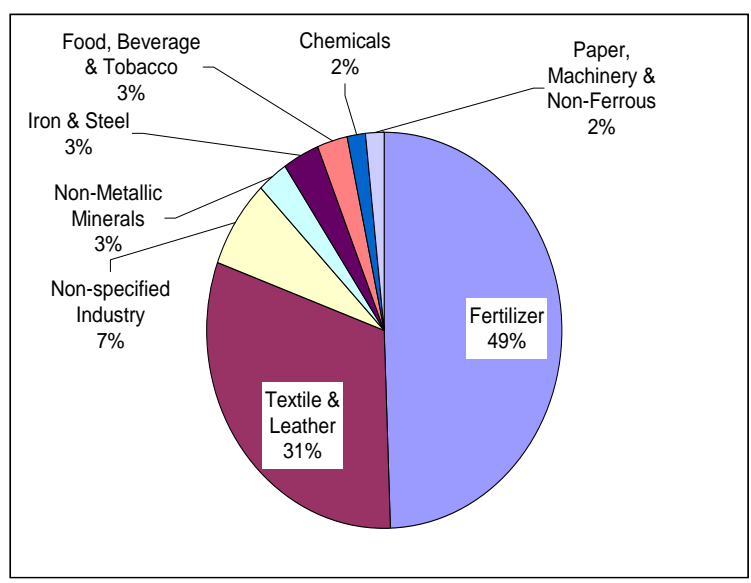

Fig. 3: Natural Gas Consumption by Different Types of Industries (2005)

Fig. 3 shows the percentage share of each type of industry for the year 2005. It shows the total consumption by the industrial sector plus captive generation by the concerned industries. It shows the dominance of the fertilizer industry, closely followed by the textile and leather group. All other sectors are quite 
small in comparison. However, some of these small consumers are energy intensive, such as the iron \& steel (mainly steel re-rolling mills), cement, ceramic and glass (non-metallic minerals group). Therefore a relatively small increase in the number of these industries can have a significant impact on the overall scenario. It should be pointed out here that the textile \& leather group is mostly export oriented, while the rest are mostly catering the domestic market. Although some ceramic product is exported, it is still quite small in comparison. There is a growing domestic market for cement, iron and steel, ceramic and glass, which is indicative of the rapid urban growth

Table 3 shows the gas consumption by the different types of industries for process heating. It includes gas burned in boilers, furnaces, kilns etc.

Table 3: Natural Gas Consumption for Process Heating (MMCM)

\begin{tabular}{|l|l|l|l|l|l|}
\hline \multirow{2}{*}{ Industry Type } & \multicolumn{3}{|l|}{ Year } & \multicolumn{5}{l|}{} \\
\cline { 2 - 6 } & $00-01$ & $01-02$ & $02-03$ & $03-04$ & $04-05$ \\
\hline $\begin{array}{l}\text { Textile and } \\
\text { Leather }\end{array}$ & 561 & 597 & 720 & 835 & 947 \\
\hline Iron \& Steel & 104 & 113 & 132 & 136 & 140 \\
\hline $\begin{array}{l}\text { Non-specified } \\
\text { Industry: }\end{array}$ & 113 & 120 & 125 & 124 & 131 \\
\hline $\begin{array}{l}\text { Food Processing, } \\
\text { Beverages and } \\
\text { Tobacco }\end{array}$ & 63 & 62 & 75 & 84 & 97 \\
\hline $\begin{array}{l}\text { Non Metallic } \\
\text { Minerals }\end{array}$ & 87 & 77 & 79 & 83 & 84 \\
\hline Chemicals & 51 & 53 & 61 & 60 & 64 \\
\hline $\begin{array}{l}\text { Pulp, Paper \& } \\
\text { Print }\end{array}$ & 12 & 12 & 12 & 12 & 12 \\
\hline $\begin{array}{l}\text { Non-Ferrous } \\
\text { Metal }\end{array}$ & 1 & 2 & 2 & 2 & 2 \\
\hline Machinery & 1 & 1 & 1 & 1 & 1 \\
\hline $\begin{array}{l}\text { Total gas for } \\
\text { Process heat }\end{array}$ & 993 & 1,037 & 1,207 & 1,337 & 1,478 \\
\hline
\end{tabular}

It is not clear whether fertilizer industry have any captive generation. The gas consumption by the fertilizer industry is usually reported as the total amount, which includes the raw material feed gas as well as the gas for process heating requirements. These are not segregated neither reported separately. The authors made a calculation based on the chemical composition of urea, which indicated that about $30 \%$ of the gas is converted into fertilizer. Thus it was assumed that $70 \%$ gas is used up in process heating. Table 4 shows the gas consumption by the fertilizer industry.
Table 4: Natural gas consumption by the fertilizer industry (MMCM)

\begin{tabular}{|l|r|r|r|r|r|}
\hline Year & $\begin{array}{r}2000- \\
01\end{array}$ & $2001-02$ & $2002-03$ & $2003-04$ & $2004-05$ \\
\hline Energy & 1,754 & 1,562 & 1,901 & 1,840 & 1,863 \\
\hline Feed & 752 & 670 & 815 & 788 & 798 \\
\hline Total & 2,505 & 2,232 & 2,715 & 2,628 & 2,661 \\
\hline
\end{tabular}

Table 5 shows the gas consumption for captive power generation. The textile and leather group consumed the highest amount of gas for captive power, maintaining a consistent trend with the process heating consumption for the same group as shown in table 3. All the other industries also showed moderately increasing trends.

Table 5: Natural gas Consumption for Captive Power Generation (MMCM)

\begin{tabular}{|l|c|c|c|c|c|}
\hline Industry Type & \multicolumn{5}{|c|}{ Year } \\
\cline { 2 - 6 } & $00-01$ & $01-02$ & $02-03$ & $03-04$ & $04-05$ \\
\hline $\begin{array}{l}\text { Textile and } \\
\text { Leather }\end{array}$ & 325 & 407 & 534 & 624 & 734 \\
\hline Iron \& Steel & 6 & 6 & 12 & 20 & 32 \\
\hline $\begin{array}{l}\text { Non-specified } \\
\text { Industry: }\end{array}$ & 65 & 154 & 149 & 211 & 251 \\
\hline $\begin{array}{l}\text { Food Processing, } \\
\text { Beverages and } \\
\text { Tobacco }\end{array}$ & 23 & 29 & 34 & 41 & 50 \\
\hline $\begin{array}{l}\text { Non Metallic } \\
\text { Minerals }\end{array}$ & 31 & 41 & 48 & 60 & 71 \\
\hline Chemicals & 26 & 28 & 32 & 33 & 34 \\
\hline $\begin{array}{l}\text { Pulp, Paper and } \\
\text { Print }\end{array}$ & 34 & 39 & 46 & 57 & 66 \\
\hline $\begin{array}{l}\text { Non-Ferrous } \\
\text { Metals }\end{array}$ & 2 & 2 & 2 & 2 & 2 \\
\hline Machinery & 3 & 3 & 3 & 3 & 3 \\
\hline $\begin{array}{l}\text { Total gas for } \\
\text { captive power }\end{array}$ & 514 & 709 & 859 & 1,051 & 1,243 \\
\hline
\end{tabular}

Fig. 4 shows the total natural gas consumption for process heating and captive power generation. Fig. 5 shows the same in a percentage representation. It shows that the share for captive generation by various industries increased from $13 \%$ to $23 \%$ of the total consumption. This trend is likely to continue unless power generation by the power utilities is boosted up and grid power is improved. Otherwise it will put extra pressure on the gas marketing companies to provide additional gas connection to increasing number of industrial units for captive generation. The captive generation to grid power will assume a high ratio, which is unusual for most countries. 


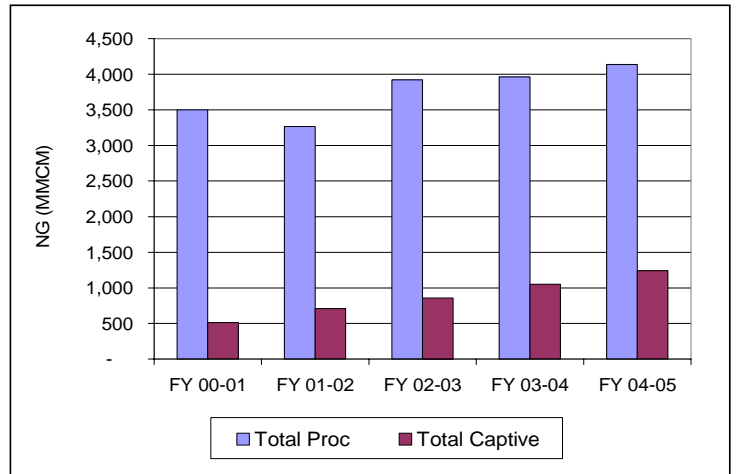

Fig. 4: Natural Gas Consumption for Process Heating and Captive Power (2001-05)

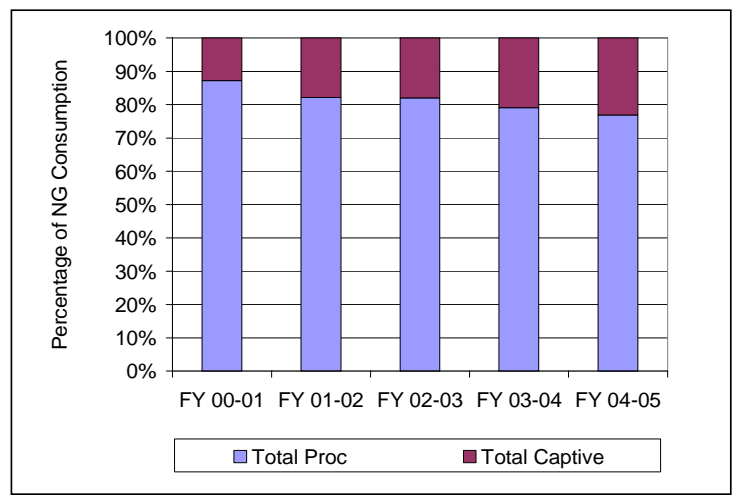

Fig. 5: Percent of natural gas consumption for process heating and captive power (2001-05)

\subsection{Consumption Intensity}

The above discussion is incomplete without an understanding of the gas consumption intensity by different industries. From the data available, there were 1,577 units of garments, textile, knitting and dying units in 2005, consuming about 920 MMCM of gas for process heating only. Thus average consumption per unit was $0.58 \mathrm{MMCM} / \mathrm{year}$. Captive generation is not included in this analysis because it is not known exactly which units were using captive generation, although individual counting showed 129 units consuming about 418 MMCM of gas. Cement, ceramic and glass industries are known to be highly energy intensive. Reliable data on cement factories were not available. There were only 31 ceramic plants consuming about 39 MMCM, i.e., $1.25 \mathrm{MMCM} /$ unit/year. Only 5 glass factories consumed 2.83 MMCM, or 0.57 MMCM/unit. The highest consumer was still the fertilizer factories. Only 7 units consumed about 1,860 MMCM, or 266 $\mathrm{MMCM} /$ unit. These are however, large plants with high volume of output. The only measure that can be taken here is to improve specific gas consumption by setting up new fertilizer plants.
These numbers however, are not sufficient to formulate gas distribution or marketing policy. It will require more data including the total output, value generated/added, energy consumption per unit of product, profitability of the industry, mass employment opportunities, contribution to national GDP, etc.

\subsection{Grouping of Industries}

Table 6 shows the various local industries considered in this paper, with the corresponding grouping and code specified by UNFCCC.

Table 6: Local industries grouping under UNFCCC

\begin{tabular}{|c|c|c|c|c|c|}
\hline 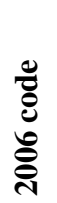 & 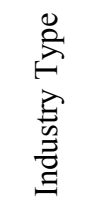 & 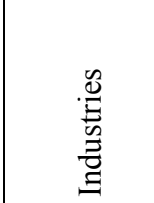 & 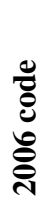 & 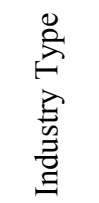 & 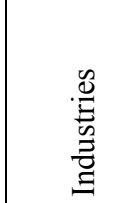 \\
\hline 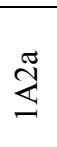 & 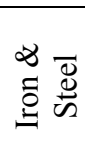 & Steel & \multirow{11}{*}{ 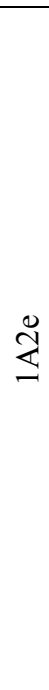 } & \multirow{11}{*}{ 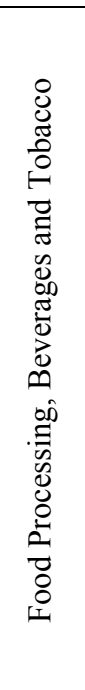 } & Agro \\
\hline \multirow{3}{*}{$\stackrel{\overparen{2}}{\overleftrightarrow{\Xi}}$} & \multirow{3}{*}{ 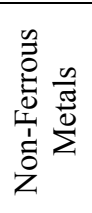 } & Cable & & & Bakery \\
\hline & & Metal & & & Dairy \\
\hline & & Molding & & & Edible oil \\
\hline \multirow{8}{*}{ 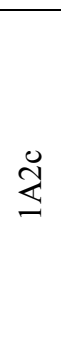 } & \multirow{8}{*}{ 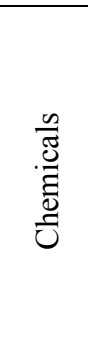 } & Chemical & & & \begin{tabular}{|l} 
Food \& \\
Beverage.
\end{tabular} \\
\hline & & Oxygen & & & Poultry \\
\hline & & Pharma. & & & Salt \\
\hline & & Plastic & & & Seed \\
\hline & & Polymer & & & Sugar \\
\hline & & Polythene & & & Tobacco \\
\hline & & Rubber & & & Tea \\
\hline & & Soap & \multirow{4}{*}{ 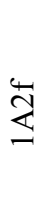 } & \multirow{4}{*}{ 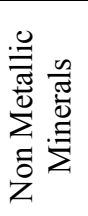 } & Cement \\
\hline \multirow{3}{*}{$\underset{\mathbb{Z}}{\mathbb{Z}}$} & \multirow{3}{*}{ 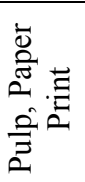 } & Board & & & Ceramics \\
\hline & & Packaging & & & Glass \\
\hline & & Paper & & & Melamine \\
\hline \multirow{6}{*}{$\underset{\mathbb{Z}}{\mathbb{S}}$} & \multirow{6}{*}{ 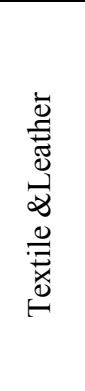 } & Dyeing & \multirow{2}{*}{ ָี } & \multirow{2}{*}{ 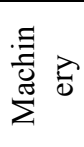 } & Battery \\
\hline & & Footwear & & & $\begin{array}{l}\text { Electronic } \\
\mathrm{s}\end{array}$ \\
\hline & & Garments & \multirow{4}{*}{ 亲 } & \multirow{4}{*}{ 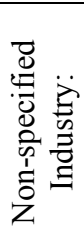 } & Jute \\
\hline & & Knitting & & & Others \\
\hline & & Spinning & & & \\
\hline & & Textile & & & \\
\hline
\end{tabular}




\section{Discussions}

Seven ammonia-urea complexes (six public and one foreign owned private) have been built in the country since 1961. The total installed capacities of these plants are 2,895,700 tons of urea and 1,886,700 tons of ammonia per year. Except for JFCL all plants are more than 20 years old. NGFF in Fenchuganj and UFFL in Ghorashal are 47 and 37 years old respectively. The Specific Energy Consumption, or SEC (MCF of natural gas consumed to produce one ton of urea) of these plants is more than double (46 MCF/Ton) than that of a state-of-the art urea plant (22 MCF/Ton). Therefore, the best option is to build totally new plants in the existing factory location. The SECs of the other four plants are also high: JFCL [30 MCF/Ton]; CUFL [36 $\mathrm{MCF} / \mathrm{Ton}] ; \mathrm{ZFCL}$ [41 MCF/Ton]; and PUFF [51 $\mathrm{MCF} / \mathrm{Ton}]$. The potential of significant gas throughput efficiency improvement by replacing these older plants is obvious (Quader, 2008). There is a significant gas saving potential in this sector, which can be as high as $25 \mathrm{BCF}$ (about $700 \mathrm{MMCM}$ ) per year.

Different studies indicate that the annual demand for urea in the country would be 3.3 to 4.5 million tonnes by FY 2024-25 (Economic Review 2005, Econ 2002). Unless new plants are set up, or existing plants are extended to implement new technology, the gas consumption trend will remain flat, and wasteful. Bangladesh is still a largely agrarian country, where the fertilizer plays a vital role. It is related to national food security. Therefore this sector must enjoy high priority. Immediate measures should be taken to renovate or install new plant so that more output is obtained from the same amount of gas.

Natural gas consumption in the textile and leather industries is steadily rising. Captive power increased almost parallel to the industrial sector's growth. Most of these establishments are export oriented, and thus significantly contributing to the national GDP. They are also creating mass employment opportunity, which has both economical and social impacts. Given the cheap labor, cheap gas, and the international reputation, this sector is likely to grow steadily. Only problems like labor unrest, significant gas price hike, or gas supply shortfall might stop the growth trend.

Although consumption in the rest of the industries is much lower, the steady rise in most of them is noticeable. A well formulated policy should take into account not only gas consumption, but also consumption intensity, output, value generated or added, profitability, mass employment, and environmental impact. Some industries, especially the textile and leather group, cause significant damage to the environment by polluting air, water resources, and agricultural lands, which may far outweigh the benefits. Health hazards caused by polluting industries have far reaching consequences, which will eventually become a great national burden. Therefore, although this group is important for export earnings and mass employment, and therefore enjoy some preferential treatment, they must be brought under strict regulations regarding environmental impact. Finally, losing concerns, if any, should not be nurtured at the expense of valuable and scare national resource.

Some discussion is also relevant regarding the pricing of gas. Currently all industries are subject to the same tariff. It is worthwhile studying the share of energy cost in the overall costing of the products. For some industries the energy cost is quite small in the total costing of the product, whereas for some energy intensive industries the energy cost is quite significant. Therefore the authorities may think about formulating price structures according to the industry types, depending on the energy cost element in their respective products.

The above analysis and discussions should be useful to prioritize in case of gas supply shortage, when gas may need to be rationed, and tariff is restructured for different industry types.

\section{Conclusion \& Recommendations}

Industry type based analysis of natural gas consumption is important to understand the nature and growth trends of various types of industries. Different industries impact the national economy in different ways. The type of analysis presented here is helpful for policy makers to prioritize the sectors in case preferential supply and tariff restructuring become necessary.

Fertilizer sector must be nurtured to ensure national food security. It requires energy efficiency measures and new plants with modern technology. Textile and leather group also deserve special attention, because it is mostly export oriented and therefore vital for national economy and mass employment. Other upcoming but highly energy intensive industries like ceramic, glass and cement need careful consideration as discussed in the preceding section. A thorough study of relationship between energy intensity, economic benefit and environmental impact of the high growth industries should be conducted before formulating a priority list for gas distribution. 
It is extremely difficult to collect industry wise consumption data given the prevailing data management practice. It will be a step forward if the MIS systems in the gas utilities are re-designed such that consumption by each individual customer and customer type is collected and reported. Another data collection system should be developed to capture the product yield, value generated or added, export and sale volumes, profitability, labor force, etc. With the modern database technology, this can be done fairly easily.

\section{References}

1. Bangladesh Oil, Gas and Mineral Corporation (Petrobangla) Annual Report 2007, Petrocenter, 3, Karwan Bazar, Dhaka.

2. Bangladesh Oil, Gas and Mineral Corporation (Petrobangla), MIS Reports, URL: www.petrobangla.org.bd.

3. Econ 2002: "Bangladesh Optimal Gas Utilization", report by Econ Centre for Economic Analysis, P.O.
Box. No 6823, St. Olva Plass, Oslo, Norway, for Norwegian Petroleum Directorate and Hydrocarbon Unit, Ministry of Energy and Mineral Resources, GOB.

4. Econ 2004: "Bangladesh Optimal Gas Utilization (Phase II)", report by Econ Centre for Economic Analysis.

5. Economic Review 2005: Economic Consultancy Cell, Finance Division, Ministry of Finance, GOB.

6. Rahman, L. (2007): "Predicting the Gas Demand in Bangladesh- A Sectorwise Regional Forecast", Masters thesis, Department of Petroleum \& Mineral Resources Department, Bangladesh University of Engineering \& Technology, Dhaka 1000, Bangladesh.

7. Quader, A.K.M.A.(2008): "Strategy for Developing the Fertilizer Sector in Bangladesh for Sustainable Agriculture", 2nd International Conference on Chemical Engineering-2008, Dhaka.

8. UNFCCC 2006 IPCC Guidelines for National Greenhouse Gas Inventories Volume 2: Energy. 